\title{
Screening of Endophytic Bacteria Isolated from Marine Sponge Haliclona fascigera for Inhibition against Clinical Isolates of Methicillin Resistant Staphylococcus aureus (MRSA)
}

\author{
Dian Handayani*, Neny Sandrawaty, Murniati Murniati, Regina Regina \\ Faculty of Pharmacy, Andalas University, Padang 25163, Indonesia.
}

\begin{tabular}{l}
\hline ARTICLE INFO \\
\hline Article history: \\
Received on: $16 / 06 / 2015$ \\
Revised on: $10 / 07 / 2015$ \\
Accepted on: $19 / 07 / 2015$ \\
Available online: $27 / 09 / 2015$ \\
\hline Key words: \\
Anti-MRSA activity, Marine \\
sponge, Haliclona fascigera, \\
Endophytic bacteria
\end{tabular}

\section{INTRODUCTION}

Nowadays, infectious disease is one of the noncontagious diseases which caused primary death in the world next after cardiovascular disease and cancer. To cure an infection, an antibiotic is involved in the treatment. When bacteria are exposed to antibiotic, most of the cells die. However some of the cells that acquire of antibiotics resistance will survive and reproduce and the new population will be drug resistant. Today many bacteria exhibit multidrug resistance, including Staphylococci, Enterococci, Gonococci, Streptococci, and others (Lee et al., 2013). In recent years, the bacteria $S$. aureus was reported to be resistant to certain antibiotic such as methycillin, cephalosporine, monobactam and carbapenem antibiotic. The bacteria was called Methicillin-Resistant Staphylococcus aureus (MRSA). In 2005, more than 19.000 cases of death in America and Britain were caused by these

\footnotetext{
* Corresponding Author

Dian Handayani, Faculty of Pharmacy, Andalas University, Padang 25163, Indonesia.Email: dianh_17@yahoo.com
}

pathogenic bacteria (Kennedy et al., 2009). MRSA has become a well-known etiological agent in a wide variety of infections. These infections have become a common problem in hospitals and in the community, and have been associated with prolonged hospital stay and increased hospital costs (Odonkor et al., 2012). Concerning this condition, the investigation of source of bioactive compounds keeps to be carried out. The natural product which was identified to have the antimicrobial activity was reported available in marine environment. Sponge is one of natural wealthy which is available in abundant amount in the sea region of Indonesia. There are a number of sponge species available. Based on Snellius-II's expedition, 830 kinds of sponge were found in the East Indonesia (Van Soest, 1989). Marine sponges are a filter-feeding organism, which form close associations with a wide variety of microorganism. Around $40 \%$ of sponge biomass is thought to contain bacterial community. This bacterial was found within in the sponge body. Some studies have shown that the symbiont has a role in production of bioactive compounds that function in ecological adaptation sponge (Proksch et al., 2003; Thakur and Muller, 2004; Zheng et al., 2005). The marine sponge Haliclona fascigera is chosen as host of isolated bacteria. 
Previous investigation has shown that this sponge was a potential source of antimicrobial metabolites compounds. The present research study aims in isolation various bacteria from marine sponge Haliclona fascigera and to evaluate their anti-MRSA activity by performing antibacterial studies.

\section{MATERIAL AND METHODS}

\section{Sponge material}

Sponge sample $H$. fascigera was taken on 5th February 2015 from the waters of the Setan Island, South Coast of West Sumatra, Indonesia at a depth of about $13 \mathrm{~m}$. It was taken as \pm 200 grams and then put into a sterile plastic bag containing sea water and stored in ice box for the isolation of endophytic bacteria and transported to the laboratory.

\section{Isolation of bacteria associated with marine sponge}

Isolation of endophytic bacteria begins with the sample surface sterilization. Sponge was rinsed with sterile sea water, then cut into small sections, taken as many as 10 grams and put into Erlenmeyer then add with sterile sea water to $100 \mathrm{ml}$. Then it was dilute until it concentration became $10^{-6}$. Then the dilution samples were taken as $1 \mathrm{ml}$ of each dilution to be inoculated on NA medium in a petri dish aseptically then incubated at $37{ }^{\circ} \mathrm{C}$ in an incubator for 24 hours. Colonies that have a different shape to the other colonies can be considered as different isolates. Then be purified to obtain pure isolates (pure bacterial colonies).

\section{Cultivation of bacteria isolates for antimicrobial activity screening}

Pure isolates obtained in the purification stage then cultured in NB. Furthermore, pure isolates taken one loop, then put in a $550 \mathrm{~mL} \mathrm{NB}$ medium and incubated in an incubator shaker at a temperature of $37^{\circ} \mathrm{C}$ for one days.

\section{Extraction of secondary metabolites from bacterial isolates}

The liquid broth of bacteria that had been grown for two days, then extracted with ethyl acetate (EtOAc) in the ratio 1: 2 . After macerated overnight, the bacteria broth was then sonicated for 5 minutes. Subsequently, ethyl acetate fraction was separated from the culture medium using a separating funnel. The solvent ethyl acetate is then evaporated with a rotary evaporator to obtain a fraction ethyl acetate. Furthermore, the resulting ethyl acetate fractions were tested for its antimicrobial bioactivity.

\section{Screening for antimicrobial activity}

The pathogenic bacteria MRSA was provided by the Laboratory of Microbiology, Public Hospital of M. Djamil Padang, West Sumatera, Indonesia. For screening of anti MRSA activity, the EtOAc extract of endophytic bacteria was tested against MRSA using the paper disk method. One pieces of $6 \mathrm{~mm}$ sterile paper disk was soaked in each of EtOAc extract $(50 \mathrm{mg} / \mathrm{ml}$ in DMSO). Paper disks were also inoculated with DMSO (negative control), and Chloramphenicol (3mg. $\mathrm{ml}^{-1}$ in DMSO) as positive controls. The disk was placed on the surface of the medium containing $10^{5}$ cell of MRSA strain. The plates were incubated at $37{ }^{\circ} \mathrm{C}$ for 24 hours. The width of inhibition zones was measured. Each treatment consisted of three replicates. The experiment was repeated twice.

\section{RESULTS AND DISCUSSION}

Marine endophytic bacteria have been attracted increasing attention in the drug discovery of new pharmaceutical and agrochemical lead compound (William, 2008). These bacteria are symbiotic with marine sponge and other invertebrates. Ravikumar et al reported that the secondary metabolite produced by endophytic bacteria might contribute to protecting their host by chemically mediated defense mechanisms for danger like predation. So that, symbiotic or associated marine bacteria are true sources of bioactive metabolites originally isolated from their host (Ravikumar et al., 2011). In this study, we have isolated 26 endophytic bacteria from marine sponge $H$. fascigera. The EtOAc extracts of endophytic bacteria were tested its bioactivity against microbial pathogens MRSA by agar diffusion method. Based on the test results of the antimicrobial activity of 26 extracts bacterial isolates in Table 1, twelve isolates can inhibit the growth of MRSA with halos between $11.1 \pm 0.17$ to $15.17 \pm 0.76$. The most effective extract against MRSA was bacteria $\mathrm{N}_{1} \mathrm{~F}_{2}$.

Table 1: Antimicrobial activity of crude extracts of endophytic bacteria from $\underline{H}$. fascigera against human pathogenic bacteria.

\begin{tabular}{ccc}
\hline No & Bacteria Kode & $\begin{array}{c}\text { Zone of Inhibition (mm) } \pm \text { Deviation } \\
\text { Standard (SD) }\end{array}$ \\
\hline 1 & $\mathrm{NM}_{1}$ & $12.17 \pm 1.6$ \\
2 & $\mathrm{~N}_{1} \mathrm{M}_{1}$ & - \\
3 & $\mathrm{~N}_{2} \mathrm{M}_{2}$ & - \\
4 & $\mathrm{NM}_{2}$ & $13.83 \pm 0.83$ \\
5 & $\mathrm{~N}_{2} \mathrm{M}_{1}$ & - \\
6 & $\mathrm{~N}_{1} \mathrm{M}_{2}$ & $7.67 \pm 0.29$ \\
7 & $\mathrm{~N}_{2} \mathrm{M}$ & - \\
8 & $\mathrm{HN}_{1}$ & $13.17 \pm 0.58$ \\
9 & $\mathrm{H}_{1} \mathrm{~N}_{1}$ & - \\
10 & $\mathrm{H}_{2} \mathrm{~N}_{2}$ & - \\
11 & $\mathrm{HN}_{2}$ & $11.1 \pm 0.17$ \\
12 & $\mathrm{H}_{2} \mathrm{~N}_{1}$ & $6.67 \pm 0.29$ \\
13 & $\mathrm{H}_{1} \mathrm{~N}_{2}$ & $13.5 \pm 1.32$ \\
14 & $\mathrm{H}_{2} \mathrm{~N}$ & $13.67 \pm 1.15$ \\
15 & $\mathrm{MR}_{1}$ & - \\
16 & $\mathrm{M}_{1} \mathrm{R}_{1}$ & $12.75 \pm 0.9$ \\
17 & $\mathrm{M}_{2} \mathrm{R}_{2}$ & - \\
18 & $\mathrm{MR}_{2}$ & $13.17 \pm 0.29$ \\
19 & $\mathrm{M}_{2} \mathrm{R}_{1}$ & $8.3 \pm 0.58$ \\
20 & $\mathrm{M}_{1} \mathrm{R}_{2}$ & $10 \pm 0.5$ \\
21 & $\mathrm{NF}_{1}$ & - \\
22 & $\mathrm{NF}_{2}$ & $12.33 \pm 0.29$ \\
23 & $\mathrm{~N}_{1} \mathrm{~F}_{2}$ & $15.17 \pm 0.76$ \\
24 & $\mathrm{~N}_{2} \mathrm{~F}_{1}$ & - \\
25 & $\mathrm{~N}_{1} \mathrm{~F}_{1}$ & - \\
26 & $\mathrm{~N}_{2} \mathrm{~F}$ & $11.17 \pm 0.76$ \\
\hline & &
\end{tabular}

Twelve extracts of bacterial endophytes which showed the middle to high level of inhibition zone against MRSA were selected for further characterization and identification based on macroscopic and microscopic evaluation, gram staining, and biochemical assay to investigate the genus (Cowan 1993). 
Table 2: Morphological and biochemical characterization for the identification of the selected marine bacterial strains.

\begin{tabular}{|c|c|c|c|c|c|c|c|c|c|c|c|c|c|c|c|c|c|c|c|c|}
\hline $\begin{array}{l}\text { Code of } \\
\text { Bacteria }\end{array}$ & 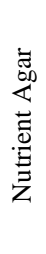 & 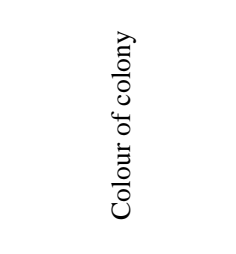 & छี & $\underset{\mathscr{E}}{\mathscr{E}}$ & $\tilde{\Xi}$ & $\stackrel{\mathscr{I}}{\mathcal{I}}$ & 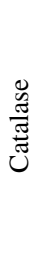 & 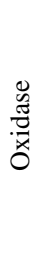 & : & 움 & $\stackrel{\varpi ّ}{D}$ & 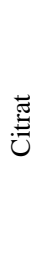 & 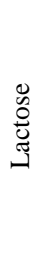 & $\begin{array}{l}0 \\
0 \\
0 \\
0 \\
0\end{array}$ & 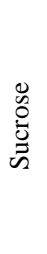 & 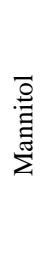 & 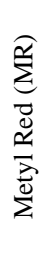 & 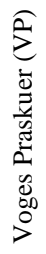 & 崩 & Identity \\
\hline $\mathrm{NF}_{2}$ & + & Yellow; Basil & + & $\mathrm{K} / \mathrm{k}$ & - & - & - & - & - & - & - & - & - & + & + & + & - & - & - & Bacillus sp.1 \\
\hline $\mathrm{NM}_{1}$ & + & Yellow; Basil & + & $\mathrm{K} / \mathrm{k}$ & - & - & - & - & - & - & - & - & - & + & + & + & - & - & - & Bacillus sp.2 \\
\hline $\mathrm{H}_{2} \mathrm{~N}$ & + & Yellow; Basil & + & $\mathrm{K} / \mathrm{k}$ & - & - & - & - & - & - & - & - & - & + & + & + & - & - & - & Bacillus sp.3 \\
\hline $\mathrm{M}_{1} \mathrm{R}_{1}$ & + & Yellow; Basil & + & $\mathrm{K} / \mathrm{k}$ & - & - & - & - & - & - & - & - & - & + & + & + & - & - & - & Bacillus sp.4 \\
\hline $\mathrm{MR}_{2}$ & + & Yellow; Basil & + & $\mathrm{K} / \mathrm{k}$ & - & - & - & - & - & - & - & - & - & + & + & + & - & - & - & Bacillus sp.5 \\
\hline $\mathrm{HN}_{1}$ & + & Yellow; Basil & + & $\mathrm{K} / \mathrm{k}$ & - & - & - & - & - & - & - & - & - & + & + & + & - & - & - & Bacillus sp.6 \\
\hline $\mathrm{H}_{1} \mathrm{~N}_{2}$ & + & Yellow; Long Basil & + & $\mathrm{K} / \mathrm{k}$ & - & - & - & + & - & - & - & - & - & - & - & - & - & - & - & Corynebacterium sp.1 \\
\hline $\mathrm{NM}_{2}$ & + & Yellow; Long Basil & + & $\mathrm{K} / \mathrm{k}$ & - & - & - & + & - & - & - & - & - & - & - & - & - & - & - & Corynebacterium sp.2 \\
\hline $\mathrm{N}_{2} \mathrm{~F}$ & + & Yellow; Long Basil & + & $\mathrm{K} / \mathrm{k}$ & - & - & - & + & - & - & - & - & - & - & - & - & - & - & - & Corynebacterium sp.3 \\
\hline $\mathrm{N}_{1} \mathrm{~F}_{2}$ & + & Yellow; Long Basil & + & $\mathrm{K} / \mathrm{k}$ & - & - & - & + & - & - & - & - & - & - & - & - & - & - & - & Corynebacterium sp.4 \\
\hline $\mathrm{HN}_{2}$ & + & White; Coccus & + & $\mathrm{K} / \mathrm{k}$ & - & - & - & + & - & - & - & - & - & - & - & - & + & + & - & Staphylococcus aureus \\
\hline $\mathrm{M}_{1} \mathrm{R}_{2}$ & + & White; Coccus & + & $\mathrm{K} / \mathrm{k}$ & - & - & - & + & - & - & - & - & - & - & - & - & + & + & - & Staphylococcus aureus \\
\hline
\end{tabular}

The result of gram staining indicated that 12 isolated bacteria included to gram positive bacteria.

It was shown by its ability to pretend the color of purple after the attachment of the violet crystal reagent. The observation of isolated bacteria under microscope showed that there were 2 kinds of isolated bacteria available in the colony such as basil and coccus. The biochemical test was performed to identify the type or genus of the symbiotic bacteria.

The test was carried out because there were any bacteria that formed specific characteristic while being reacted to specific biochemical reagent so that the type or genus could be identified. Based on the tests above, 12 genus of the bacteria were successfully identified. 6 bacteria belong to Bacillus sp. Which were then labeled as

Bacillus sp.1; Bacillus sp.2; Bacillus sp.3; Bacillus sp.4; Bacillus sp.5; and Bacillus sp., 4 bacteria belong to Corynebacterium $s p$. that were then labeled as Corynebacterium sp.1; Corynebacterium sp.2; Corynebacterium sp.3; and Corynebacterium sp.4. and another 2 bacteria belong to Staphylococcus aureus (Table 2).

However, further research will be conducted to isolate the anti-MRSA compound from the most active bacteria such as Corynebacterium sp.4 (Bacteria $\mathrm{N}_{1} \mathrm{~F}_{2}$ ).

\section{CONCLUSIONS}

The present study brings out the potential anti-MRSA activity of endophytic bacteria from $H$. fascigera. It can also be conclude that endophytic bacteria might be used as an alternative to produce the antibiotic used in pharmaceutical on the basis inhibition of pathogenic microorganisms. However, further research pharmacological studies on isolation and identification, safety and efficacy needs to be done in determining antibiotic compounds produced by those endophytic bacteria.

\section{ACKNOWLEDGEMENT}

This research was funded by Directorate General of Higher Education Ministry of National Education, Indonesia, 030/SP2H/PL/DIT.LITABMAS/II/2015, February, 2015. The authors are also grateful to the authorities of Laboratory of Microbiology, Public Hospital of M. Djamil, Padang, Indonesia for providing us the MRSA culture.

\section{REFERENCES}

Bari SB, Mahajan BM, and Surana SJ. Resistance to antibiotic: a challenge in chemotherapy. Indian Journal of Pharmaceutical education and Research, 2008; 42 (1):3-11

Cowan Steel's. 1993. Manual for the identification of medical bacteria, $3^{\text {rd }}$ ed, Cambridge University Press.

Kennedy J, Baker P, Piper P, Cotter D, Walsh M, Mooij MJ, Bourke MB, Rea MC, O’Connor MP, Ross P, Hill C, O'Gara F, Marchesi $\mathrm{JR}$, and Dobson ADW. Isolation and analysis of bacteria with antimicrobial activities from the marine sponge Haliclona simulans collected from Irish waters. Mar. Biotechnol.2009;11: 384-396.

Lee DS, Eom SH, Lee MS and Kim YM. 2013. Marine bacteria are an attractive source to overcome the problems of antibiotic-resistant Staphylococcus aureus. In: Kim SK, ed. Marine Microbiology: Bioactive compound and biotechnological application. Wiley-VCH $\mathrm{GmbH} \& \mathrm{Co}$. KGaA, Germany 83 - 96

Odonkor, S.T., Mercy J.N., and Kennedy K.A. Prevalence and antibiotic susceptibility profile of Methicillin Resistant Staphylococcus aureus in Accra, Ghana. Microbiology Research, 2012; 3(20).

Proksch, P, Ebel, R, Edrada, RA, Schuup, P, Lin, WH, Sudarsono, Wray, V, Steube, K.Detection of pharmacologically active natural products using ecology. Selected examples from Indopasific marine invertebrates and sponge-derived fungi. Pure and Appl Chem, 2003; 75(2): 343-352.

Ravikumar S, Jacob Inbaneson S, Uthiraselvam M, Rajini Priya S, Ramu A, Beula Banerjee M. Diversity of endophytic actinomycetes from Karangkadu mangrove ecosystem and its antibacterial potential against bacterial pathogens. J Pharm Res, 2011; 4(1); 294-296

Thakur, NL, \& Muller, WEG. Biotechnological potential of marine sponges. Current Science, 2004; vol. 86: 11-27.

Zheng, L, Chen, H, Han, X, Yan, X. Antimicrobial screening and active compound isolation from marine bacterium NJ6-3-1 associated 
with the sponge Hymeniacidon parleve. World Journal of Microbiol and Biotech, 2005; 21: 201-206.

Van Soest, R. W. 1989. The Indonesian Sponge Fauna: A Status Report. Institute of Taxonomic Zoology, University of Amsterdam.

Williams PG. Panning for chemical gold: marine bacteria as a source of new therapeutics. Trends in Biotechnol. 2008; 27(1); 42-52.

World Health Organization. 2013. World Health Statistic. Geneva : WHO Press.

\section{How to cite this article:}

Dian Handayani, Neny Sandrawaty, Murniati Murniati, Regina Regina. Screening of Endophytic Bacteria Isolated from Marine Sponge Haliclona fascigera for Inhibition against Clinical Isolates of Methicillin Resistant Staphylococcus aureus (MRSA). J App Pharm Sci, 2015; 5 (09): 139-142. 